\title{
Evaluation of food and beverage television advertising during children's viewing time in Spain using the UK nutrient profile model
}

\author{
$M^{a}$ Mar Romero-Fernández ${ }^{1,2, *} \dagger$, Miguel Ángel Royo-Bordonada ${ }^{1}$ and \\ Fernando Rodríguez-Artalejo ${ }^{3,4}$ \\ ${ }^{1}$ Escuela Nacional de Sanidad, Instituto de Salud Carlos III, Madrid, Spain: ${ }^{2}$ Unidad de Medicina Preventiva, \\ Hospital General Universitario de Ciudad Real, Ciudad Real, Spain: ${ }^{3}$ Departamento de Medicina Preventiva y \\ Salud Pública, Facultad de Medicina, Universidad Autónoma de Madrid, Madrid, Spain: ${ }^{4}$ CIBER de \\ Epidemiología y Salud Pública (CIBERESP), Barcelona, Spain
}

Submitted 23 October 2011: Final revision received 14 June 2012: Accepted 18 June 2012: First published online 27 July 2012

\begin{abstract}
Objective: To evaluate the nutritional quality of products advertised on television (TV) during children's viewing time in Spain, applying the UK nutrient profile model (UKNPM).

Design: We recorded $80 \mathrm{~h}$ of four general TV station broadcasts during children's viewing time in May and June 2008, and identified all advertisements for foods and beverages. Nutritional information was obtained from the product labels or websites and from food composition tables. Each product was classified as healthy (e.g. gazpacho, a vegetable juice) or less healthy (e.g. potato crisp snacks) according to the UKNPM criteria.

Setting: Four free-of-charge TV channels in Spain: two national channels and two regional ones.

Subjects: TV commercials of food and beverages.

Results: A total of 486 commercials were broadcast for ninety-six different products, with a mean frequency of $5 \cdot 1$ advertisements per product. Some $61 \cdot 5 \%$ of the ninety-six products were less healthy, and the percentage was higher for foods $(74 \cdot 1 \%)$. All $(100 \%)$ of the breakfast cereals and $80 \%$ of the non-alcoholic drinks and soft drinks were less healthy. Of the total sample of commercials, $59.7 \%$ were for less healthy products, a percentage that rose to $71 \cdot 2 \%$ during children's reinforced protection viewing time.

Conclusions: Over half the commercials were for less healthy products, a proportion that rose to over two-thirds during the hours of special protection for children. This suggests that applying the UKNPM to regulate food advertising during this slot would entail the withdrawal of most food commercials in Spain. TV advertising of products with low nutritional quality should be restricted.
\end{abstract}

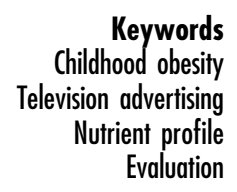

Childhood obesity is a global public health problem ${ }^{(1,2)}$. The prevalence of childhood obesity in Spain, where one of every three children is overweight, is among the highest in Europe and is comparable only to that of the UK and other Mediterranean countries ${ }^{(3,4)}$. Childhood obesity is associated with other cardiovascular risk factors and diabetes mellitus, as well as with musculoskeletal and psychosocial disorders in childhood and adolescence ${ }^{(5)}$. Moreover, obese children have a higher risk of obesity and CVD in adulthood ${ }^{(6)}$.

$\dagger$ Correspondence address: Fundación Canaria de Investigación y Salud, Servicio de Evaluación y Planificación del Servicio Canario de la Salud, C/Pérez de Rozas 5, $4^{a}$ planta, E-38004 Santa Cruz de Tenerife, Spain.
Television (TV) viewing is associated with childhood obesity $^{(7)}$, primarily due to the influence of advertising on food preferences and on the purchase and consumption of foods high in fat, salt or sugar (HFSS) ${ }^{(8,9)}$. In 2006, the International Obesity Taskforce elaborated the Sydney Principles to reduce the commercial promotion of foods and beverages to children ${ }^{(10)}$ and in 2010, the WHO recommended policies to implement these principles ${ }^{(11)}$. However, most countries have promoted measures only to self-regulate advertising, which have been of modest or doubtful effectiveness ${ }^{(12)}$. In Spain, the "Code of selfregulation of the advertising of food products directed at minors, prevention of obesity and health (PAOS code)' was implemented in $2005^{(13)}$. The PAOS code supervises 
the creative design, characters and truth of the message transmitted in each commercial aimed at children under the age of 12 years, but does not restrict children's exposure to advertising (either the amount of advertising to children or the times when it can be screened) and does not consider the nutritional quality of the advertised products. Moreover, recent evidence shows that compliance with the code is low ${ }^{(14,15)}$

Since 2007, the UK has gone a step further by regulating advertising as a function of the nutritional quality of products, limiting advertisements for HFSS foods and beverages on children's channels and at times with a large viewing audience of children for the rest of the channels ${ }^{(16)}$. The definition of a 'less healthy' product is established in accordance with the UK nutrient profile model (UKNPM) developed by the Food Standards Agency ${ }^{(17)}$. The model uses a straightforward scoring system which recognizes the contribution made by beneficial nutrients that are particularly important in children's diet (protein, fibre, fruit and vegetables, nuts) and assigns worse scores to foods with nutrients that children should eat less of (energy, saturated fats, salt and sugars). Its application in the UK has markedly reduced advertising of these types of products ${ }^{(16)}$. Thus, the objectives of the present study were to: (i) evaluate, for the first time in Spain, the nutritional quality of food and beverage advertising on TV applying the UKNPM; and (ii) estimate the potential effect of implementing this system to regulate food advertising during children's viewing time. To this end, we estimated the percentage of advertisements for less healthy products during normal and special children's protection viewing times.

\section{Methods}

\section{Study design}

We selected commercials for food products (beverages, foods, restaurant chains and their menus) broadcast on four Spanish TV channels during May and June 2008. The broadcasts were recorded during two days, one workday and one weekend day. We avoided school vacation days, holidays and the day before holidays, so that the commercials would be representative of broadcasts during most of the year. We chose two national television channels, one public (TVE-1) and another private (Antena 3), and two regional channels (Canal Sur and TeleMadrid). The national channels were selected because they have the largest child audience ${ }^{(18)}$; specifically, the seven most popular programmes among children were broadcast on Antena 3 (five) and TVE1 (two). The regional channels were chosen because they are representative of the regions with higher (Andalusia) and lower (Madrid) prevalence of obesity in Spain ${ }^{(19)}$.

In all, $80 \mathrm{~h}$ of programming were recorded. The recordings were made from 08.00 to 11.00 hours, from
13.00 to 15.00 hours and from 17.00 to 22.00 hours, to include programming during the time of special protection for children (known as 'reinforced protection for children' in Spain) and other times of normal protection when there is a large audience of children ${ }^{(20)}$; these times were always within the viewing period established for children in Spain (06.00 to 22.00 hours). The products advertised were grouped into food categories adapted from those used in the health registry of foods in Spain ${ }^{(21)}$. Alcoholic beverages were excluded from the analysis because they were not considered in the $\mathrm{UKNPM}^{(16)}$.

\section{UK nutrient profiling model}

Each food product advertised was evaluated with the UKNPM, a step-by-step scoring system that assesses the nutrient content of $100 \mathrm{~g}$ of the product. Points are allocated in the first step for the less healthy components (energy, sugar, saturated fat and sodium) and in the second step for the healthy components (fibre, protein, fruit, vegetables and nuts); in the third step, the final score is obtained by a simple algorithm that depends on the points obtained in the previous steps ${ }^{(17)}$. Foods with a final score of $\geq 4$ points and beverages scoring $\geq 1$ point are classified as less healthy (e.g. potato crisp snacks), in contrast to those considered healthy (e.g. gazpacho, an Andalusian vegetable juice). The UKNPM has been validated by comparing its results with expert opinion ${ }^{(22)}$.

As an example, the nutritional profile of Donuts ${ }^{\circledR}$ Classic is calculated in the following manner.

Total 'A' score:

$$
\begin{aligned}
& \text { [Points for energy }=5(1721 \mathrm{~kJ})] \\
& \quad+[\text { points for saturated fat }=10(12 \mathrm{~g})] \\
& \quad+[\text { points for sugars }=4(20 \mathrm{~g})] \\
& \quad+[\text { points for sodium }=2(230 \mathrm{mg})]=21 .
\end{aligned}
$$

Total 'C' score:

[Points for fruit, vegetables and nut content $=0(0 \%)$ ]

$$
\begin{aligned}
& +[\text { points for fibre }=3(3 \mathrm{~g})] \\
& +[\text { points for protein }=3(6 \mathrm{~g})]=6 .
\end{aligned}
$$

As this food scores 11 or more 'A' points but scores less than 5 points for fruit, vegetables and nuts, the overall score is calculated without taking into account the protein points. Thus

$$
\begin{aligned}
& \text { Overall score }=(\text { total 'A' points })-(\text { fibre points }+ \text { fruit, } \\
& \text { vegetables and nuts points only })=18 \text { points. }
\end{aligned}
$$

Then, this food was classified as 'less healthy'.

The nutrient content was obtained from the labels of each product or when this was not possible, from the website for the product/brand/company during 2009 and 2010. For twenty-three products (23.5\%) information could not be obtained for one or more of their components (primarily grams of saturated fat, sugar, fibre or sodium) 
from either the product labels or the websites. In these cases food composition tables were consulted: Spanish tables ${ }^{(23,24)}$ for fifteen products and international tables ${ }^{(25,26)}$ for three products. Lastly, we used the manufacturer's data obtained in response to our information request in three products, and the composition of a similar product of the same firm for one product. Only one product (Royne ${ }^{\circledR}$ soya ice cream) was excluded from the analysis because its nutrient content could not be obtained from any of these sources.

When a product came in different flavours or varieties, we evaluated the one that could be identified in the image used in the advertisement or calculated the mean score for all the available varieties. For example, Pizzas Casatarradellas ${ }^{\circledR}$ markets a number of pizza varieties with different ingredients. However, we evaluated the 'ham and cheese' pizza because we identified this variety in the firm advertisement. For fast-food 'mixed meals' (burger or 'meal combos'), we selected the main component of the meal, as has been done in a previous study ${ }^{(27)}$. In the case of generic advertisements of a business brand or firm, we selected the most representative food (e.g. in the advertisements for Burger King ${ }^{\circledR}$ and McDonalds ${ }^{\circledR}$ we evaluated the cheeseburger because this product is marketed in both firms with the same name). Finally, when the product advertised was not marketed at the time of evaluation, we calculated the score for the equivalent varieties that were available.

\section{Statistical analysis}

The percentage of all food products advertised that were considered less healthy was calculated according to the UKNPM. To estimate the potential effect of applying the UKNPM in food advertising to children in Spain, we considered the number and frequency of advertisements for each product. Differences in the percentage of less healthy products between various product categories were examined with the $\chi^{2}$ test. Statistical significance was established at two-tailed $P<0 \cdot 05$. The analyses were performed using the STATA statistical software package version $10 \cdot 0^{(28)}$.

\section{Results}

During the $80 \mathrm{~h}$ of television recorded, 486 food advertisements were broadcast, representing $21.6 \%$ of total advertisements, a percentage that increased to $22 \cdot 3 \%$ during children's reinforced protection viewing time. The advertisements were for ninety-six different products, with a mean repetition frequency of $5 \cdot 1$ advertisements per product. Of the ninety-six products, $60 \cdot 4 \%$ were for foods and $39.6 \%$ for beverages. The most frequent food categories were non-alcoholic drinks and soft drinks $(10 \cdot 4 \%)$, followed by breakfast cereals $(8 \cdot 3 \%)$.

According to the UKNPM, $61.5 \%$ of the products advertised were less healthy $(74 \cdot 1 \%$ of the foods and $42 \cdot 1 \%$ of the beverages; $P<0 \cdot 01)$. By food category,
$100 \%$ of the breakfast cereals, chocolates and chocolate spreads, meat hamburgers and cold meat, pizzas and snacks (cereal bars and potato crisp snacks) were considered less healthy (Table 1).

The mean nutrient content of the food products advertised on TV channels is shown in Table 2. Each $100 \mathrm{~g}$ of a typical product provides a mean of $896 \mathrm{~kJ}, 23 \cdot 1 \%$ of which comes from sugars, $9 \cdot 9 \%$ from protein, $39 \cdot 1 \%$ from fats and $14 \cdot 7 \%$ from saturated fats. Compared with the nutritional goals of the $\mathrm{WHO}^{(29)}$, the products were high in sugars, saturated fats and sodium, and low in complex carbohydrates.

Table 3 shows the nutrient profile of the food advertisements according to the UKNPM. Some $59 \cdot 7 \%$ of the advertisements were for less healthy products $(66.6 \%$ of those for foods and $49.5 \%$ of those for beverages; $P<0 \cdot 01)$. In comparison with the sample of products advertised ( $n$ 96, data shown in Table 1 ), the percentage of advertisements for less healthy products was higher for 'non-alcoholic beverages and soft drinks' (80.0\% $v$. $93 \cdot 1 \%)$, 'biscuits, cakes and pastry mix' ( $85 \cdot 7 \% v .92 \cdot 9 \%)$, 'liquid yoghurts' $(57 \cdot 1 \%$ v. 67.9\%), 'cheese and cheese products' $(66 \cdot 7 \% \quad v .80 \cdot 0 \%)$ and 'sauces and dressing' $(75 \cdot 0 \% v \cdot 90 \cdot 0 \%)$; whereas it was lower for 'coffee and cocoa' $(57 \cdot 1 \%$ v. $44 \cdot 1 \%)$, 'chewing gum and sugars confection' $(50 \cdot 0 \% \quad v \cdot 33 \cdot 3 \%)$ and 'milk-based desserts and ice cream' $(33 \cdot 3 \% v \cdot 17 \cdot 6 \%)$. The percentage of advertisements for less healthy products was higher in children's reinforced protection viewing time than in normal protection time $(71.2 \%$ v. 53.9; $P<0.01)$ and during the weekend compared with weekdays $(62 \cdot 3 \% v$. 55.7; $P<0 \cdot 05)$.

\section{Discussion}

Our results show that the majority of foods and beverages advertised during children's airtime on TV in Spain are HFSS products. Applying the UKNPM, $61.5 \%$ of all products and $100 \%$ of the breakfast cereals, chocolates and chocolate spreads, meat hamburgers and cold meat, pizzas and snacks advertised were less healthy. Implementation of a system to regulate advertising in Spain based on the UKNPM during children's reinforced protection viewing time would require the withdrawal of over two-thirds of the commercials for food in this airtime.

The results of recent studies in other countries are similar to ours. In New Zealand in 2007, $66.3 \%$ of the products advertised were less healthy ${ }^{(27)}$, while in Canada and the UK in 2006 the proportion of less healthy foods advertised was $65.7 \%$ and $54.5 \%$, respectively ${ }^{(30)}$, as compared with $59 \cdot 7 \%$ in our study. However, sugars in the products advertised in Canada and the UK provided $16 \cdot 0 \%$ of total energy, lower than the $23 \cdot 1 \%$ found in Spain. This finding is notable because sugar intake is associated with higher levels of cardiovascular risk factors 
Table 1 Evaluation of food products advertised on four Spanish television channels in May and June 2008, according to the UK nutrient profile model

\begin{tabular}{|c|c|c|c|}
\hline & \multirow[b]{2}{*}{ Total $n$} & \multicolumn{2}{|c|}{ Less healthy } \\
\hline & & $n$ & $\%$ \\
\hline \multicolumn{4}{|l|}{ Product type } \\
\hline Beverage & 38 & 16 & $42 \cdot 1$ \\
\hline Food & 58 & 43 & $74 \cdot 1$ \\
\hline \multicolumn{4}{|l|}{ Food category } \\
\hline Biscuits, cakes and pastry mix & 7 & 6 & $85 \cdot 7$ \\
\hline Bread and bakeries & 1 & 0 & 0 \\
\hline Breakfast cereals & 8 & 8 & $100 \cdot 0$ \\
\hline Cereal bars & 4 & 4 & $100 \cdot 0$ \\
\hline Cheese and cheese products & 3 & 2 & $66 \cdot 7$ \\
\hline Chewing gum and sugars confection & 4 & 2 & $50 \cdot 0$ \\
\hline Chocolate spreads & 1 & 1 & $100 \cdot 0$ \\
\hline Chocolates & 3 & 3 & $100 \cdot 0$ \\
\hline Coffee (fresh and instant) and cocoa (instant) & 7 & 4 & $57 \cdot 1$ \\
\hline Dietary substitutes & 1 & 1 & $100 \cdot 0$ \\
\hline Juices & 3 & 0 & 0 \\
\hline Liquid yoghurts & 7 & 4 & $57 \cdot 1$ \\
\hline Meat hamburgers and cold meat & 6 & 6 & $100 \cdot 0$ \\
\hline Milk & 4 & 0 & 0 \\
\hline Milk-based desserts and ice cream & 9 & 3 & $33 \cdot 3$ \\
\hline Non-alcoholic drinks and soft drinks & 10 & 8 & $80 \cdot 0$ \\
\hline Pizzas & 2 & 2 & $100 \cdot 0$ \\
\hline Potato crisp snacks & 2 & 2 & $100 \cdot 0$ \\
\hline Prepared soups & 1 & 0 & 0 \\
\hline Rice & 1 & 0 & 0 \\
\hline Sauces/dressing & 4 & 3 & $75 \cdot 0$ \\
\hline Vegetables & 2 & 0 & 0 \\
\hline Water & 6 & 0 & 0 \\
\hline Total & 96 & 59 & $61 \cdot 5$ \\
\hline
\end{tabular}

Table 2 Nutrient contents of the ninety-six food products advertised on four Spanish television channels in May and June 2008

\begin{tabular}{|c|c|c|c|c|c|}
\hline \multirow[b]{3}{*}{ Dietary factor } & \multicolumn{5}{|c|}{ Sample of products ( $n$ 96) } \\
\hline & \multirow{2}{*}{$\begin{array}{l}\text { Nutrient profile per } 100 \mathrm{~g} \text { of } \\
\text { product (mean) }\end{array}$} & \multicolumn{2}{|c|}{ Energy equivalence* } & \multirow{2}{*}{$\begin{array}{c}\% \text { with respect to } \\
\text { total kJ }\end{array}$} & \multirow{2}{*}{$\begin{array}{l}\text { Recommended } \\
\text { intaket }\end{array}$} \\
\hline & & $\mathrm{kJ}$ & kcal & & \\
\hline $\mathrm{kJ}$ & $896 \cdot 004$ & $896 \cdot 004$ & $214 \cdot 15$ & 100 & \\
\hline Protein $(\mathrm{g})$ & $5 \cdot 28$ & $88 \cdot 366$ & $21 \cdot 12$ & $9 \cdot 9$ & $10-15 \%$ \\
\hline Carbohydrate (g) & $27 \cdot 62$ & $462 \cdot 248$ & $110 \cdot 48$ & $51 \cdot 6$ & $55-75 \%$ \\
\hline Sugars (g) & $12 \cdot 35$ & $206 \cdot 689$ & $49 \cdot 40$ & $23 \cdot 1$ & $<10 \%$ \\
\hline Fats $(\mathrm{g})$ & $9 \cdot 31$ & $350 \cdot 577$ & $83 \cdot 79$ & $39 \cdot 1$ & $15-30 \%$ \\
\hline Saturated fats (g) & 3.50 & $131 \cdot 796$ & $31 \cdot 50$ & $14 \cdot 7$ & $<10 \%$ \\
\hline Sodium (mg) & $222 \cdot 24$ & - & - & - & $<2 \mathrm{~g} / \mathrm{d}$ \\
\hline
\end{tabular}

${ }^{*}$ Protein and carbohydrate are considered to provide $16.736 \mathrm{~kJ} / \mathrm{g}(4 \mathrm{kcal} / \mathrm{g})$ and fats, $37.656 \mathrm{~kJ} / \mathrm{g}(9 \mathrm{kcal} / \mathrm{g})^{(51)}$.

tRanges of population nutrient intake goals; WHO/FAO Expert Consultation ${ }^{(29)}$.

in children ${ }^{(31)}$, adolescents ${ }^{(32)}$ and adults $^{(33)}$. In the USA in $2007,98 \%$ of the breakfast cereals advertised to children on TV were HFSS $^{(34)}$, the same as in our study. Overall, most investigations of nutrient quality of the foods advertised on TV consistently conclude that most of them are HFSS products ${ }^{(35-38)}$.

In Spain, as in other countries ${ }^{(37)}$, the food sector produces the most TV advertisements with a $15-31 \%$ share of advertising, a proportion that is even higher during children's reinforced protection viewing time ${ }^{(14,39)}$. Moreover, in our study the percentage of advertisements for less healthy products was higher during the protected viewing time $(71 \cdot 2 \% v \cdot 53 \cdot 9 \%)$. This finding contrasts with results from Canada and the UK before the new regulation was applied, where no differences were observed in the proportion of food advertisements for 'less healthy' products during or around programmes of particular appeal to children compared with the rest of the programmes ${ }^{(30)}$.

The epidemic of childhood obesity, combined with intense commercial pressure on children, has triggered an international appeal from health professionals, consumers and WHO to reduce the negative impact of advertising on children's eating habits ${ }^{(10,11,14,40)}$. In this context, in 2007 the UK government banned the advertising of less healthy 
Table 3 Evaluation of the food advertisements on four Spanish television channels in May and June 2008, according to the UK nutrient profile model

\begin{tabular}{|c|c|c|c|}
\hline & \multirow[b]{2}{*}{ Total $n$} & \multicolumn{2}{|c|}{ Less healthy } \\
\hline & & $n$ & $\%$ \\
\hline \multicolumn{4}{|l|}{ Product type } \\
\hline Beverage & 196 & 97 & $49 \cdot 5$ \\
\hline Food & 290 & 193 & $66 \cdot 6$ \\
\hline \multicolumn{4}{|l|}{ Food category } \\
\hline Biscuits, cakes and pastry mix & 28 & 26 & $92 \cdot 9$ \\
\hline Bread and bakeries & 13 & 0 & 0 \\
\hline Breakfast cereals & 50 & 50 & $100 \cdot 0$ \\
\hline Cereal bars & 13 & 13 & $100 \cdot 0$ \\
\hline Cheese and cheese products & 10 & 8 & $80 \cdot 0$ \\
\hline Chewing gum and sugars confection & 12 & 4 & $33 \cdot 3$ \\
\hline Chocolate spreads & 5 & 5 & $100 \cdot 0$ \\
\hline Chocolates & 8 & 8 & $100 \cdot 0$ \\
\hline Coffee (fresh and instant) and cocoa (instant) & 34 & 15 & $44 \cdot 1$ \\
\hline Dietary substitutes & 1 & 1 & $100 \cdot 0$ \\
\hline Juices & 9 & 0 & 0 \\
\hline Liquid yoghurts & 81 & 55 & $67 \cdot 9$ \\
\hline Meat hamburgers and cold meat & 24 & 24 & $100 \cdot 0$ \\
\hline Milk & 19 & 0 & 0 \\
\hline Milk-based desserts and ice cream & 74 & 13 & $17 \cdot 6$ \\
\hline Non-alcoholic drinks and soft drinks & 29 & 27 & $93 \cdot 1$ \\
\hline Pizzas & 15 & 15 & $100 \cdot 0$ \\
\hline Potato crisp snacks & 17 & 17 & $100 \cdot 0$ \\
\hline Prepared soups & 1 & 0 & 0 \\
\hline Rice & 6 & 0 & 0 \\
\hline Sauces/dressing & 10 & 9 & $90 \cdot 0$ \\
\hline Vegetables & 5 & 0 & 0 \\
\hline Water & 22 & 0 & 0 \\
\hline \multicolumn{4}{|l|}{ Day of broadcast } \\
\hline Weekday & 194 & 108 & $55 \cdot 7$ \\
\hline Weekend & 292 & 182 & $62 \cdot 3$ \\
\hline \multicolumn{4}{|l|}{ Television channel } \\
\hline TVE1 & 135 & 84 & $62 \cdot 2$ \\
\hline A3 & 184 & 115 & $62 \cdot 5$ \\
\hline TeleMadrid & 80 & 57 & $71 \cdot 3$ \\
\hline Canal Sur & 87 & 34 & $39 \cdot 1$ \\
\hline \multicolumn{4}{|l|}{ Reinforced protection viewing time } \\
\hline Yes & 163 & 116 & $71 \cdot 2$ \\
\hline No & 323 & 174 & $53 \cdot 9$ \\
\hline Total & 486 & 290 & $59 \cdot 7$ \\
\hline
\end{tabular}

products in programmes with a large audience of children, a measure that was expanded in 2009 to include all advertising for these types of products on children's channels ${ }^{(16)}$. There is evidence that this is one of the most cost-effective population interventions to control obesity and obesity-related diseases in adults ${ }^{(41)}$ and children ${ }^{(42)}$. In Spain, which has a level of childhood obesity similar to that of the UK, a policy of self-regulation of food advertising was set in 2005 by establishing a conduct code for advertisements targeting children under 12 years of age; however, the code does not consider either the nutritional quality of products or the frequency of advertisements. Thus it lacks the capacity to reduce commercial pressure on children, even if there was strict compliance with it - a goal far from realization according to available data ${ }^{(15)}$. In the USA, implementation of a code of self-regulation that does consider nutritional aspects has also failed to show any improvement in the nutritional quality of the products advertised after 3 years of operation ${ }^{(43)}$. In contrast, in the
UK children's exposure to advertisements for less healthy products has been reduced by over one-third in 2 years ${ }^{(16)}$. In Spain, the recently passed Law on Food Safety and Nutrition once again opts for self-regulation, with no mention of the nutritional quality of products, and establishes a 1-year period for the adoption of the codes of conduct regulating commercial communications of foods and beverages aimed at children under 15 years of age ${ }^{(44)}$. In view of our results, to effectively help in promoting healthy habits among children, such codes should consider the nutritional quality of the advertised products. An additional benefit of the profiling scheme is reformulation of processed foods. The reduction of salt in breakfast cereals in the UK reported in a recent study ${ }^{(45)}$ suggests that marketing regulation may stimulate manufacturers to produce products that are lower in sugar and salt, thereby avoiding the advertising restrictions ${ }^{(22,46)}$.

To adequately interpret our results, a few methodological comments are in order. The most important limitation of our 
study is the relatively small number of advertisements and hours of broadcasting that were recorded. However, a larger sample would be unlikely to change the conclusions, since it would probably result in the same advertisements being repeated several more times. Nor is it likely that selection of other TV channels would change the findings because both the number and type of advertisements are similar on the different channels. One study limitation inherent in the UKNPM is the requirement to use $100 \mathrm{~g}$ of product, as this is larger than the usual portion of certain foods consumed, such as olive oil. The UKNPM classifies this food as less healthy because of the high fat and energy content in $100 \mathrm{~g}$ of the product. This hardly changes our results given that this product represents only $0 \cdot 21 \%$ of advertisements, but we believe the UKNPM should be modified for use in Spain because the promotion of olive oil is intended only to encourage the choice of this oil over others that are less healthy. On the other hand, the UKNPM has proved able to identify food products with a better nutritional profile ${ }^{(47,48)}$. Finally, for twenty-three products information could not be obtained for one or more of their components from either the product labels or the websites. However, we succeeded to obtain this information from alternative reasonably valid sources, mainly the 14th edition of well-known food composition tables in Spain ${ }^{(24)}$, providing the energy and nutrient composition of over 700 foods marketed in Spain. These tables are continuously updated and are commonly used by Spanish researchers to convert food consumption into nutrient intake.

In Spain, the poor nutritional quality of the products advertised on TV, which is of particular concern during the reinforced protection time, is promoting unhealthy eating habits in children. Article 46 of the Law on Food Safety and Nutrition (passed in March 2011) establishes that 'the codes of conduct regulating commercial communications of foods and beverages aimed at children under age 15 will have the goal of helping to prevent obesity and promote healthy habits'. However, these codes have proved ineffective in achieving this objective. Therefore, in contrast, the use of the UKNPM in Spain would lead to a reduction of over $70 \%$ in children's exposure to commercials for HFSS products during the reinforced protection viewing time, in line with recent WHO recommendations and consumer demand $^{(11,49)}$. In fact, two channels (Cartoon Network and Boomerang) licensed by Ofcom (the Office of Communication) in the UK have recently been forced to withdraw the sponsorship by HFSS food products ${ }^{(16,50)}$. Regulation of television advertising of food products in Spain should ban the advertising of HFSS food and beverages during children's viewing time.

\section{Acknowledgements}

This research received no specific grant from any funding agency in the public, commercial or not-for-profit sectors.
The authors declare that there are no conflicts of interest. Ethical approval was not required. M.M.R.-F. took part in the design of the study, bibliographical research, interpretation of results and editing every part of the manuscript. She did the fieldwork collecting the data and analysed the data in collaboration with M.A.R.-B. M.A.R.-B. took part in the design of the study, bibliographical research, interpretation of results, editing every part of the manuscript and checking it. F.R.-A. took part in the design of the study, bibliographical research, interpretation of the results and manuscript editing and checking.

\section{References}

1. Cui W (2011) Poor nutrition is increasing rates of overweight in developing countries. BMJ 342, 1787.

2. International Obesity Taskforce (2010) Overweight children around the world. http://www.iaso.org/iotf/obesity/?map= children (accessed June 2011).

3. Organization for Economic Co-operation and Development (2010) Health at a Glance: Europe 2010. Paris: OECD Publishing; available at http://dx.doi.org/10.1787/health_ glance-2010-en

4. Salcedo V, Gutiérrez-Fisac JL, Guallar-Castillón P et al. (2010) Trends in overweight and misperceived overweight in Spain from 1987 to 2007. Int J Obes (Lond) 34, $1759-1765$.

5. Lawlor DA, Benfield L, Logue J et al. (2010) Association between general and central adiposity in childhood, and change in these, with cardiovascular risk factors in adolescence: prospective cohort study. BMJ 341, 6224.

6. Reilly JJ \& Wilson D (2006) ABC of obesity. Childhood obesity. BMJ 333, 1207-1210.

7. Pérez A, Hoelscher DM, Springer AE et al. (2011) Physical activity, watching television, and the risk of obesity in students, Texas, 2004-2005. Prev Chronic Dis 8, A61.

8. Zimmerman FJ \& Bell JF (2010) Associations of television content type and obesity in children. Am J Public Health 100, 334-340.

9. World Health Organization (2011) Chronic Diseases and Health Promotion. Reducing the Marketing of Unhealthy Foods to Children. Geneva: WHO; available at http://www. who.int/chp/media/news/releases/2011_1_marketing/en/

10. Swinburn B, Sacks G, Lobstein T et al. (2008) The 'Sydney Principles' for reducing the commercial promotion of foods and beverages to children. Public Health Nutr 11, 881-886.

11. World Health Organization (2010) Set of Recommendations on the Marketing of Foods and Non-Alcoholic Beverages to Children. Geneva: WHO.

12. Hawkes C (2007) Regulating and litigating in the public interest: regulating food marketing to young people worldwide: trends and policy drivers. Am J Public Health 97, 1962-1973.

13. Spanish Ministry of Health and Consumer Affairs (2005) Code of Self-Regulation of the Advertising of Food Products Directed at Minors, Prevention of Obesity and Health (PAOS code). Madrid: Ministerio de Sanidad y Consumo; available at http://www.naos.aesan.msssi.gob.es/naos/ ficheros/empresas/Codigo_PAOS_ingles.pdf

14. Organización de Consumidores y Usuarios (2010) Publicidad de alimentos en programas infantiles. Hay que cortar por lo sano. OCU-SALUD 92, 22-25.

15. Romero-Fernández MM, Royo-Bordonada MA \& RodríguezArtalejo F (2010) Compliance with self-regulation of television food and beverage advertising aimed at children in Spain. Public Health Nutr 13, 1013-1021. 
16. Office of Communication (2010) HFSS Advertising Restrictions. Final Review. London: Ofcom.

17. Food Standards Agency (2009) Nutrient Profiling Technical Guidance. London: FSA; available at http://collections. europarchive.org/tna/20100927130941/http://food.gov.uk/ multimedia/pdfs/techguidenutprofiling.pdf

18. Defensor del Pueblo (2010) Programación y Contenidos de la televisión e Internet: La opinión de los menores sobre la protección de sus derechos. Informes, estudios y documentos no. 25. Madrid: Defensor del Pueblo.

19. Serra Majem L, Ribas Barba L, Aranceta Bartrina J et al. (2003) Childhood and adolescent obesity in Spain. Results of the enKid study (1998-2000). Med Clin (Barc) 121, 725-732.

20. Núñez Ladevéze L, Gómez Amigo S \& Vázquez Barrio T (2007) La audiencia infantil en la CAM. Ámbitos 16, 257-281.

21. Agencia Española de Seguridad Alimentaria y Nutrición (2011) Registro General Sanitario de Empresas Alimentarias y Alimentos. Listado de claves. http://www.aesan.msc.es/ AESAN/docs/docs/listado_claves.pdf (accessed April 2011).

22. Lobstein T \& Davies S (2009) Defining and labelling 'healthy' and 'unhealthy' food. Public Health Nutr 12, 331-340.

23. Mataix Verdú J \& Mañas Almendros M (1998) Tabla de Composición de Alimentos Españoles. Granada: Universidad de Granada.

24. Moreiras O, Carbajal A, Cabrera L et al. (2010) Tablas de Composición de Alimentos, 14th ed. Madrid: Pirámide.

25. CalorieKing Australia (2006-2011) Nutritional Information (database online). http://www.calorieking.com.au/foods/ topsearches.php

26. Food Standards Australia New Zealand (2006) NUTTAB 2006 Online version (database online). http://www. foodstandards.gov.au/consumerinformation/nuttab2010/ nuttab2010onlinesearchabledatabase/onlineversion.cfm? \&action $=$ default

27. Jenkin G, Wilson N \& Hermanson N (2009) Identifying 'unhealthy' food advertising on television: a case study applying the UK Nutrient Profile model. Public Health Nutr 12, 614-623.

28. Hills M \& De Stavola BL (2006) A Short Introduction to Stata for Biostatistics. London: Timberlake Consultants.

29. World Health Organization (2003) Diet Nutrition and the Prevention of Chronic Diseases. Joint WHO/FAO Expert Consultation. WHO Technical Report Series no. 916. Geneva: WHO.

30. Adams J, Hennessy-Priest K, Ingimarsdottir S et al. (2009) Food advertising during children's television in Canada and the UK. Arch Dis Child 94, 658-662.

31. Collison KS, Zaidi MZ, Subhani SN et al. (2010) Sugarsweetened carbonated beverage consumption correlates with BMI, waist circumference, and poor dietary choices in school children. BMC Public Health 10, 234.

32. Welsh JA, Sharma A, Cunningham SA et al. (2011) Consumption of added sugars and indicators of cardiovascular disease risk among US adolescents. Circulation 123, 249-257.

33. Welsh JA, Sharma A, Abramson JL et al. (2010) Caloric sweetener consumption and dyslipidemia among US adults. JAMA 303, 1490-1497.

34. Schwartz MB, Ross C, Harris JL et al. (2010) Breakfast cereal industry pledges to self-regulate advertising to youth: will they improve the marketing landscape? J Public Health Policy 31, 59-73.

35. Batada A, Seitz MD, Wootan MG et al. (2008) Nine out of 10 food advertisements shown during Saturday morning children's television programming are for foods high in fat, sodium, or added sugars, or low in nutrients. J Am Diet Assoc 108, 673-678.

36. Castillo-Lancellotti C, Pérez-Santiago O, Rivas-Castillo C et al. (2010) Análisis de la publicidad de alimentos orientada a niños y adolescentes en canales chilenos de televisión abierta. Rev Esp Nutr Comunitaria 16, 90-97.

37. Keller SK \& Schulz PJ (2011) Distorted food pyramid in kids programmes: a content analysis of television advertising watched in Switzerland. Eur J Public Health 21, 300-305.

38. Kelly B, Halford JC, Boyland EJ et al. (2010) Television food advertising to children: a global perspective. Am J Public Health 100, 1730-1736.

39. Pérez Pérez ML (2008) Informe General sobre Menores y Televisión en Andalucía. Sevilla: Consejo Audiovisual de Andalucía.

40. Organización de Consumidores y Usuarios (2008) Con la comida no se juega. OCU-SALUD 81, 10-13.

41. Sassi F, Cecchini M, Lauer J et al. (2009) Improving Lifestyles, Tackling Obesity: The Health and Economic Impact of Prevention Strategies. OECD Health Working Paper no. 48. Paris: OECD.

42. Magnus A, Haby MM, Carter R et al. (2009) The costeffectiveness of removing television advertising of high-fat and/or high-sugar food and beverages to Australian children. Int J Obes (Lond) 33, 1094-1102.

43. Kunkel D, McKinley C \& Wright P (2009) The Impact of Industry Self-Regulation on the Nutritional Quality Foods Advertised on Television to Children. Oakland, CA: Children Now.

44. Boletín Oficial del Estado (2011) Ley 17/2011, de 5 de julio, de seguridad alimentaria y nutrición. Boletín Oficial de Estado no. 160, 6 Jul 2011, sec. I, p. 71283. http://www. boe.es/boe/dias/2011/07/06/pdfs/BOE-A-2011-11604.pdf (accessed August 2011).

45. Which? (2012) What's in Your Bowl? The Most Popular Breakfast Cereals Compared, Briefing. London: Which?

46. Rayner M, Scarborough P \& Lobstein T (2009) The UK Ofcom Nutrient Profiling (NP) Model. Defining 'Healthy' and 'Unhealthy' Foods and Drinks for TV Advertising to Children. Oxford and London: University of Oxford and IOTF; available at http://www.dph.ox.ac.uk/bhfhprg/ publicationsandreports/acad-publications/bhfhprgpublished/ nutrientprofilemodel

47. Arambepola C, Scarborough P \& Rayner M (2008) Validating a nutrient profile model. Public Health Nutr 11, 371-378.

48. Scarborough P, Boxer A, Rayner M et al. (2007) Testing nutrient profile models using data from a survey of nutrition professionals. Public Health Nutr 10, 337-345.

49. Organización de Consumidores y Usarios (2012) Enganchados al marketing. OCU-SALUD 100, 18-21.

50. Office of Communication (2009) Ofcom Broadcast Bulletin issue 147, 7 December. London: Ofcom; available at http:// www.ofcom.org.uk/tv/obb/prog_cb/obb147/Issue147.pdf

51. Martinez Hernández JA \& Portillo Baquedano MP (2011) Fundamentos de Nutrición y Dietética. Bases metodológicas y aplicaciones. Madrid: Editorial Médica Panamericana. 